\title{
Myoepithelial Carcinoma: A Rare Neoplasm of the Breast
}

\author{
Kuo-Chun Liao ${ }^{a}$ Wen-Ying Lee ${ }^{b}$ Ming-Jenn Chen ${ }^{a}$ \\ aDepartment of Surgery, \\ ${ }^{b}$ Department of Pathology, Chi Mei Medical Center, Yong Kang City Tainan, Taiwan, R.O.C.
}

\section{Key Words}

Malignant myoepithelioma - Breast neoplasm · p63 . Surgical oncology

\section{Summary}

Background: Malignant myoepitheliomas of the breast are extremely rare. There has been a limited number of published reports of myoepithelial carcinomas originating from the breast. Case Report: We describe a malignant myoepithelioma of the breast in a 56-year-old woman. Histological examination showed polygonal epithelioid cells and spindle cells with moderate to marked nuclear atypia. Immunohistochemistry showed reactivity in the spindle cells for smooth muscle actin, cytokeratin (AE1/AE3), and p63, indicating a myoepithelial cell lineage of tumor cells. The patient underwent radical surgical excision of the lesion and axillary lymph node dissection. She demonstrated no evidence of recurrence over an 11-month follow-up. Conclusions: We suggest myoepithelial carcinomas of the breast be managed with appropriate surgical clearance. A multidisciplinary approach is usually required.

\section{Introduction}

Myoepithelial cells of the breast are present as an intervening layer in the normal mammary glandular structures, located between the epithelial cells and the basement membrane of the secretory elements of the mammary duct system. They have important roles in mammary gland development and physiology. Furthermore, myoepithelial cells maintain the basement membrane surrounding the mammary ducts, and provide a physical barrier between epithelial cells and the

\author{
Schlüsselwörter \\ Malignes Myoepitheliom - Neoplasie der Brust · p63 . \\ Chirurgische Onkologie
}

\section{Zusammenfassung}

Hintergrund: Maligne Myoepitheliome der Brust sind extrem selten. Es existiert nur eine begrenzte Anzahl an Berichten über aus dem Brustgewebe stammende myoepitheliale Karzinome. Fallbericht: Wir beschreiben den Fall eines malignen Myoepithelioms der Brust bei einer 56-jährigen Patientin. Die histologische Untersuchung zeigte polygonale epitheloide Zellen und Spindelzellen mit moderater bis starker Kernatypie. Die immunhistochemische Untersuchung ergab Reaktivität in den Spindelzellen auf Glattmuskel-Aktin, Zytokeratin (AE1/AE3) und p63, was auf eine myoepitheliale Abstammung der Tumorzellen hindeutet. Eine radikale chirugische Resektion des Tumors und Exstirpation der Achsellymphknoten wurden durchgeführt. Während eines 11-monatigen Follow-ups zeigte die Patientin keine Anzeichen eines Rückfalls. Schlussfolgerungen: Wir schlagen bei myoepithelialen Karzinomen der Brust eine angemessene chirurgische Resektion vor. Ein multidisziplinärer Ansatz ist in der Regel erforderlich.

stroma. Myoepithelial cells have dual structural characteristics of epithelial and smooth muscle cells [1]. The most common location of myoepitheliomas is the salivary gland [2-4]. Extrasalivary locations include soft tissue, skin, breast, and lung. Myoepithelial carcinoma of the breast is composed of malignant myoepithelial cells which are usually spindleshaped but may occasionally be polygonal. Mammary tumors with predominantly myoepithelial elements are extremely uncommon.

\begin{tabular}{ll}
\hline KARGER & ๑ 2010 S. Karger GmbH, Freiburg \\
Fax +497614520714 & Accessible online at: \\
Information@Karger.de & www.karger.com/brc \\
www.karger.com &
\end{tabular}

\section{KARGER}




\section{Case Report}

A 56-year-old, postmenopausal woman presented to a medical center with a palpable mass in the left breast 1 month before admission to our hospital. Physical examination disclosed a firm, movable mass of $3.5 \times 2.5 \mathrm{~cm}$ in size in the lower inner quadrant of the left breast. No masses or lymphadenopathy were palpable in the axilla. The remainder of the examination was unremarkable. The patient had an 18-year history of rheumatoid arthritis and type 2 diabetes mellitus. Menarche had occurred at the age of 13 years, and she had been pregnant 4 times (first pregnancy at the age of 28 years) and given birth 2 times. She had never used oral contraceptives or received exogenous hormone replacement therapy. The patient had never smoked cigarettes, and would occasionally drink 1-2 alcoholic beverages. There was no family history of breast cancer.

Mammography revealed regional architectural distortion (fig. 1 A) Ultrasound showed a $27 \times 18 \times 30 \mathrm{~mm}$ mass with an irregular, ill-defined and hypoechogenic appearance (fig. 1 B). The histological examination of a simultaneous core biopsy revealed the presence of atypical myoepithelial cells. After options were discussed, the patient elected to undergo a wide excision. Pathological examination revealed that the tumor extended with an infiltrative border into the nearby structures. The neoplasm was composed of polygonal, epithelioid cells and spindle cells with moderate to marked nuclear atypia (fig. 2 A). Mitotic figures were readily identifiable. Immunohistochemistry showed strong immunoreactivity for smooth muscle actin, cytokeratin (AE1/AE3), and p63, indicating a myoepithelial cell lineage of tumor cells (fig. 2 B). Ki-67 immunostaining exhibited a proliferation rate of around $30 \%$. The lesion was diagnosed as a malignant myoepithelioma. As the surgical margins were positive, a modified radical mastectomy with axillary lymph node clearance was performed, which left no residual foci of malignancy. No metastasis was detected in the axillary lymph nodes. In 11 months of follow-up, there has been no evidence of recurrence.

\section{Discussion}

Tavassoli [5] proposed that there are 3 types of myoepithelial lesions in the breast: myoepitheliosis, adenomyoepithelioma, and malignant myoepithelioma. Myoepitheliosis and adenomyoepitheliomas consist of a significant population of myoepithelial cells admixed with epithelial cells. Adenomyoepitheliomas are further classified into spindle cell, tubular, and lobulated variants based on the growth patterns. Malignant myoepithelioma is composed purely of myoepithelial cells. It is an extremely rare tumor.

Myoepithelial carcinomas are difficult to diagnose. Unlike adenomyoepitheliomas, which exhibit distinctive combined patterns of luminal epithelial and myoepithelial differentiation $[6,7]$, they are composed purely of spindle cells, and consequently virtually impossible to differentiate from spindle cell carcinomas and sarcomas on morphological examination [8-10]. It is essential to be able to recognize myoepithelial carcinomas in order to learn more about their natural history and response to treatment. Myoepithelial carcinomas are characterized by an infiltrating proliferation of plump, atypical spindle cells with readily identifiable mitotic figures [8-10]. These tumors are composed purely of spindled cells without any epithelial cell component. Although most malignant myoepitheliomas are of the spindle cell type, glandular type epithelial

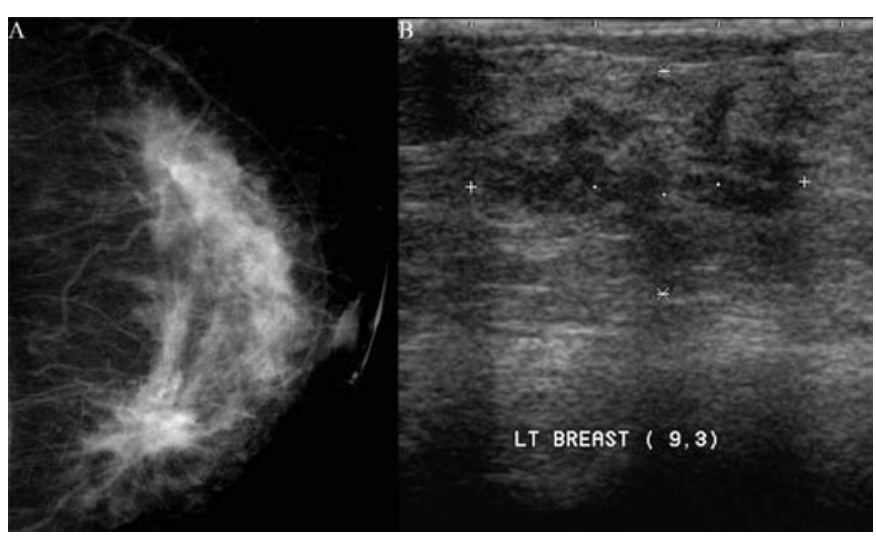

Fig. 1. A Mammogram of the left breast showing regional architectural distortion without microcalcification at the lower inner quadrant.

B Sonography showing a slightly hypoechoic mass with irregular margins.



Fig. 2. A Hematoxylin and Eosin stained section of the lesion showing a spindle cell neoplasm with marked nuclear atypia and frequent mitoses $\times 400)$. B Section of the lesion immunostained for $\mathrm{p} 63$ showing strong reactivity in the tumor cells $(\times 400)$.

structures with lumen and microvilli have been demonstrated ultrastructurally. It is important to distinguish myoepithelial carcinoma from other forms of breast lesions composed of spindle cells. These mainly include monophasic sarcomatoid carcinoma, fibromatosis, and pure spindle cell sarcoma [11]. Overlap in their histological appearances may lead to misinterpretation or underdiagnosis.

Monophasic sarcomatoid carcinomas contain little or no discernible epithelial component. Some monophasic sarcomatoid carcinomas may co-express actin immunoreactions, making separation from myoepithelial carcinoma difficult. The diagnosis is usually established using antibodies to keratin of variable molecular weight. Sarcomatoid carcinomas behave in a manner similar to that of high-grade carcinomas [12, 13]. Fibromatosis is well recognized in the breast. The diagnosis is mainly based on histological features. It is composed of proliferation of myofibromatosis and fibroblasts which comprise fascicles of spindle cells with usually minimal pleomorphism and few or no mitoses $[14,15]$. Immunohistochemically, fibromatosis often expresses actin, and occasionally desmin and S100. Cytokeratins are not expressed [16]. It is important to exclude the deceptively bland monophasic sarcomatoid carcinoma before contemplating a diagnosis of fibromatosis. Pure spindle cell sarcomas should only be diagnosed after being distinguished from other resembling lesions, including spindle cell myoepithelioma [8] and monophasic sarcomatoid carci- 
noma [13, 14]. Immunohistochemical and ultrastructural examinations are usually helpful in making a differential diagnosis, showing a lack of epithelial components in most pure spindle cell sarcomas of the breast. The presence of S100 protein and focal positivity for cytokeratin favors a myoepithelioma.

The patient's clinical picture is consistent with a myoepithelial carcinoma of breast according to histological characteristics and expression of immunohistochemical positivity for cytokeratin and myoepithelial markers. The patient had a complete excision of the lesion without receiving adjuvant radiotherapy, chemotherapy, or hormone therapy. So far, the regular follow-up evaluations adopt an uneventful course.

Over the past decade, there has been significant progress in the discovery and application of antibody markers that can be used in the immunohistochemical identification of myoepithelial cells. Myoepithelial cells can be difficult to detect on routine section. Increasing attention has been given to the aiding role of immunohistochemical stains [17-20]. For optimal clinical utility, an ideal marker of myoepithelium would manifest absolute sensitivity and specificity for myoepithelial cells. In particular, such a marker would not cross-react with other cells in the breast, such as stromal myofibroblasts, vascular smooth muscle cells, or luminal epithelial/carcinoma cells. Currently widely used myoepithelial markers include S100 protein, the basement membrane proteins, type IV collagen and laminin, high molecular weight cytokeratins, and smooth muscle actins, all having incomplete sensitivities and specificities that make them imperfect candidate myoepithe- lial markers. P63, a homologue of $\mathrm{p} 53$, is a sensitive and relatively specific marker for myoepithelial cells [21-24]. It is a nuclear stain with high sensitivity and minimal cross reactivity. It is not expressed in myofibroblasts or blood vessels, therefore circumventing the diagnostic pitfalls associated with smooth muscle-related myoepithelial markers. Overall, p63 has high sensitivity and specificity for myoepithelial cells and is a very useful marker.

In conclusion, myoepithelial carcinomas are extremely rare lesions of the breast. Myoepithelial carcinomas are difficult to diagnose. The development of immunohistochemistry aids in the histological examination of breast in which identification of myoepithelial carcinoma is not feasible from the morphological features alone. Myoepithelial carcinomas pursue an aggressive clinical course with locally invasive and metastatic potential [25, 26]. Radical excision with elective adjuvant radiotherapy is the therapeutic strategy of choice in order to minimize local recurrence. Multiple aspects including age, comorbidity, and the patient's autonomy should be taken into consideration while drawing a treatment plan. To date, there is limited published data on the biological behavior and longterm clinical outcome of mammary myoepithelial carcinomas. We therefore recommend a multidisciplinary approach based on an experienced team to formulate a treatment modality.

\section{Conflict of Interest}

The authors declare no conflict of interest.

\section{References}

1 Ahmed A: The myoepithelium in human breast carcinoma. J Pathol 1974;113:129-35.

$\checkmark 2$ Chaudhry AP, Satchidanand S, Peer R, Cutler LS: Myoepithelial cell adenoma of the parotid gland: a light and ultrastructural study. Cancer 1982;49:288293.

3 Crissman JD, Wirman JA, Harris A: Malignant myoepithelioma of the parotid gland. Cancer 1977;40:3042-9.

4 Sciubba JJ, Brannon RB: Myoepithelioma of salivary glands: report of 23 cases. Cancer 1982;49:56272.

5 Tavassoli FA: Myoepithelial lesions of the breast. Myoepitheliosis, adenomyoepithelioma and myoepithelial carcinoma. Am J Surg Pathol 1991;15:554-68.

6 Jabi M, Dardick I, Cardigos N: Adenomyoepithelioma of the breast. Arch Pathol Lab Med 1988;112:73-6.

7 Choi JS, Bae JY, Jung WH: Adenomyoepithelioma of the breast: its diagnostic problems and histogenesis. Yonsei Med J 1996;37:284-9.

8 Bigotti G, Di Giogio CG: Myoepithelioma of the breast: histologic, immunologic and electronmicroscopic appearances. J Surg Oncol 1986;32:58-64.

-9 Cartagena N Jr, Cabello-Inchausti B, Willis I, Poppiti R Jr: Clear cell myoepithelial neoplasm of the breast. Hum Pathol 1988;19:1239-43.
10 Enghardt MH, Hale JH: An epithelial and spindle cell breast tumour of myoepithelial origin: an immunohistochemical and ultrastructural study. Virchows Arch 1989;416:177-84

11 Al-Nafussi A: Spindle cell tumours of the breast: practical approach to diagnosis. Histopathology 1999;35:1-13.

12 Foschini MP, Dina RE, Eusebi V: Sarcomatoid neoplasms of the breast: proposed definitions biphasic and monophasic sarcomatoid mammary neoplasms. Semin Diagn Pathol 1993;10:128-36.

13 Gutman H, Pollock RE, Janjan NA, Johnston D: Biological distinctions and therapeutic implications of sarcomatoid neoplasia of epithelial carcinoma of the breast. J Am Coll Surg 1995;180:193-9.

14 Wargotz ES, Norris HJ, Austin RM, Enzinger FM: Fibromatosis of the breast. A clinical and pathological study of 28 cases. Am J Surg Pathol 1987;11:38-45.

15 Rosen PP, Ernsberger D: Mammary fibromatosis. A benign spindle-cell tumor with significant risk for local recurrence. Cancer 1989;63:1363-9.

16 Devouassoux-Shisheboran M, Schammel MD, Man YG, Tavassoli FA: Fibromatosis of the breast: agecorrelated morphofunctional features of 33 cases. Arch Pathol Lab Med 2000;124:276-80
17 Catena F, Santini D, Di Saverio S, Ansaloni L, Taffurelli M: Adenomyoepithelioma of the breast: an intricate diagnostic problem. Breast Care 2008;3:125-7.

18 El-Zammar OA, Haidar A: Immunoreactivity of ductal cells with putative myoepithelial markers: a potential pitfall in breast carcinoma. Ann Diagn Pathol 2003;7:335.

19 Shah VI, Flowers CI, Douglas-Jones AG, Dallimore NS, Rashid M: Immunohistochemistry increases the accuracy of diagnosis of benign papillary lesions in breast core needle biopsy specimens. Histopathology 2006;48:683-91.

20 Moritani S, Ichihara S, Kushima R, Okabe H, Bamba M, Kobayashi TK, Hattori T: Myoepithelial cells in solid variant of intraductal papillary carcinoma of the breast: a potential diagnostic pitfall and a proposal of an immunohistochemical panel in the differential diagnosis with intraductal papilloma with usual ductal hyperplasia. Virchows Arch 2007;450:539-47.

21 Tse GM, Tan PH, Lui PC, Gilks CB, Poon CS, Law BK, Lam WW: The role of immunohistochemistry for smooth muscle actin, p63, CD10 and cytokeratin 14 in the differential diagnosis of papillary lesions of the breast. J Clin Pathol 2007;60:315-20. 
22 Barbareschi M, Pecciarini L, Cangi MG, Macrì E, Rizzo A, Viale G, Doglioni C: p63, a p53 homologue, is a selective nuclear marker of myoepithelial cells of the human breast. Am J Surg Pathol 2001;25:1054-60.

23 Kaufmann O, Fietze E, Mengs J, Dietel M: Value of p63 and cytokeratin 5/6 as immunohistochemical markers for the differential diagnosis of poorly differentiated and undifferentiated carcinomas. Am J Clin Pathol 2001;116:823-30.
( Garcia S, Zucoloto S: The relationship between p63 and p53 expression in normal and neoplastic breast tissue. Arch Pathol Lab Med 2003;127:33640.

25 Shiraishi T, Nakayama T, Fukutome K, Watanabe M, Murata T: Malignant myoepithelioma of the breast metastasizing to the jaw. Virchows Arch 1999;435:520-3.
26 Chen PC, Chen CK, Nicastri AD, Wait RB: Myoepithelial carcinoma of the breast with distant metastasis and accompanied by adenomyoepitheliomas. Histopathology 1994;24:543-8. 